\title{
Injury and condemnation data of pigs at slaughterhouses with federal inspection in the State of Paraná, Brazil, as indicators of welfare during transportation
}

\begin{abstract}
Mariam El Tasse ${ }^{1 *}$ (D) Carla Forte Maiolino Molento ${ }^{1}$ (i)
${ }^{1}$ Programa de Pós-graduação em Ciências Veterinárias (PPGCV), Departamento de Zootecnia (DZUFPR), Universidade Federal do Paraná (UFPR), Laboratório de bem-estar animal da Universidade Federal do Paraná (LABEA-UFPR), 80035050, Curitiba, PR, Brasil. E-mail: eltassemariam@gmail.com. "Corresponding author.

ABSTRACT: Pigs transportation is a critical stage for their welfare and can directly influence the rates of carcass condemnation. The objective of this research was to study the injuries and condemnation data recorded in the Federal Inspection System (SIF) as potential welfare indicators during pig transport. In federally inspected slaughterhouses in the State of Paraná, Brazil, from january 2011 to December 2016, $1.4 \%(602,006)$ of carcasses were condemned, $15.0 \%(90,426)$ as a result of injuries related to transportation. From total condemnation cases, $12.1 \%(72,759)$ were due to traumatic injury, $2.5 \%(15,144)$ to PSE, $0.4 \%(2,327)$ to dead on arrival and $0.03 \%$ (196) to other transportation welfare indicators. There was no correlation between the condemnation rates and the meteorological data. The results exposed the need for improvement in pig transport conditions. In addition, this study allowed us to point out possible improvements in the collection of nosographic data into the SIF's Management Information System (SIGSIF), such as inclusion of other injuries associated with welfare restrictions, standardization of the terms that already exist in the system, improvement in the indicator measurements, development of regulations and training for professionals involved. Results suggested that SIGSIF data are useful for monitoring the welfare of pigs during transportation, with potential for refinement from improvements in data recording.

Key words: animal welfare, condemnation, inspection, pig, slaughterhouse, transportation.
\end{abstract}

Lesões e condenações de suínos em abatedouros com inspeção federal no Estado do Paraná, Brasil, como indicadores de bem-estar no transporte

RESUMO: O transporte de suínos é um estágio crítico para seu bem-estar e pode influenciar os índices de condenação de carcaça. O objetivo deste trabalho foi estudar as lesões e condenações registradas no Sistema de Inspeção Federal (SIF) como potenciais indicadores de bem-estar durante o transporte de suinos. Nos abatedouros paranaenses com SIF, de janeiro de 2011 a dezembro de 2016, 1,4\% (602.006) das carcaças foram condenadas, sendo 15\% (90.426) em decorrência de lesões potencialmente relacionadas ao transporte. Do total de condenações, $12,1 \%$ (72.759) foram por lesão traumática, 2,5\% (15.144) por PSE, 0,4\% (2.327) por mortalidade na chegada ao abatedouro e 0,03\% (196) por outros indicadores de bem-estar no transporte. Não houve correlação entre índices de condenação e dados meteorológicos. O trabalho expôs a necessidade de aprimoramento nas condições de transporte dos suínos. Além disso, permitiu apontar melhorias na coleta de dados no Sistema de Informações Gerenciais do SIF (SIGSIF), como a inclusão de outras lesões associadas a restrições de bem-estar, padronização dos termos existentes no SIGSIF, aperfeiçoamento na mensuração dos indicadores, construção de normativas e treinamento dos profissionais envolvidos. Os resultados sugerem que os dados do SIF são úteis para o monitoramento de bem-estar de suínos durante o transporte, com potencial de refinamento a partir de melhorias no registro de dados.

Palavras-chave: abatedouro, bem-estar animal, condenação, inspeção, suíno, transporte.

\section{INTRODUCTION}

According to the Ministry of Agriculture, Livestock and Supply (MAPA, 2016), Brazil ranks fourth regarding worldwide pig production and exportation, and according to data from the Brazilian Association of Animal Protein (ABPA, 2016), from 2010 to 2014 there was a $6.7 \%$ growth in the national production. According to the State Office of Agriculture and Supply of Paraná (SEAB, 2017), in 2016 a total of $8,881,059$ pigs were slaughtered in this State. In face of the number of animals involved, the consideration of their welfare becomes especially relevant. GEVERINK et al. (1998) stated that the transport to the slaughterhouse is the most stressing event for animals. Such fact is related to the high susceptibility of pigs to stress during the loading of the vehicle at the farm, transport and arrival at the slaughterhouse, which may cause severe welfare decrease and even death (DALMAU et al., 2009).

BROOM (2008) states that any disease, lesion or death due to transportation is important for the evaluation of animal welfare, which additionally includes behavioral aspects, as well as 
the physiological and carcass quality parameters. According to EFSA (2012), the presence of lesions on arrival at the slaughterhouse and on the carcass right after slaughter may be considered as a transport welfare indicator. In this sense, PEREIRA \& CORASSA (2014) reported that welfare of the pigs during transit may influence carcass condemnation. According to HARLEY et al. (2014), data obtained from slaughter inspection are a useful source for monitoring the prevalence of diseases and the welfare conditions the animals were subjected to. In addition, NANNONI et al. (2016) stated that the registration of causes of carcass condemnation in pigs allows for the study of their welfare, their diseases, as well as the understanding of the causes for the losses at the slaughterhouse.

The objective of this research is to study the lesion and condemnation data registered in the Federal System of Inspection (SIF) in the Parana State as potential indicators of pig welfare during transport (IWT).

\section{MATERIALS AND METHODS}

Nosographic data related to the condemnation of pig carcasses obtained in the SIF Management Information System (SIGSIF, 2017), from the establishments under federal inspection located in Paraná, from January 2011 to December 2016, were studied. Seventy-two monthly reports were obtained by accessing SIGSIF online data. Afterwards, carcass data on partial or total condemnation were selected. The selection of the condemnation reasons with potential for working as IWT was done based on the literature, on meetings with MAPA official veterinarians and on SIGSIF data. Reasons elected were those related to anemia, acid meats, myopathy, exudative myopathy, strained meats, injury, traumatic lesion, prolonged decubitus and dead on arrival. Grouping of the data was organized by reasons of condenation reported in SIGSIF, the Regulation of the Industrial and Sanitation Inspection of Animal Origin Products - RIISPOA (MAPA, 2017), as well as the guidance from MAPA veterinarians (Table 1). Other reasons that were not selected as IWT were named General Type Indicators (GTI). Files were extracted using the Slaughtering Consulting per State/Species as research filter, and the pigs slaughtered in the State of Paraná were then selected. The identification of reasons occurred on pig carcass.

Additionally, monthly meteorological data (INMET, 2017) on total precipitation (in milimeters), average compensated temperature (in degrees Celsius) and average relative humidity (in percentage), from January 2011 to December 2016, were studied with the aim of evaluating the existence of correlations between condemnation and the meteorological data.

Descriptive statistics and analyses of correlation between condemnation rates and meteorological data were performed. The ChiSquare Test (SIEGEL, 1975) was used to test the association between the type of condemnation and the type of indicator (confidence interval $=95 \%$, level of significance $=0.05$ ). The software used was R (R CORE TEAM, 2016).

\section{RESULTS AND DISCUSSION}

The data set comprised 17 registered establishments, with 41,313,434 slaughtered pigs and

Table 1 - Grouping of the SIF's Management Information System ([SIGSIF][UdW1][M2]) reasons as indicators of animal welfare during transportation.

\begin{tabular}{lc}
\hline Indicators of animal welfare during transportation & Existing Reasons at SIGSIF \\
\hline Pale, Soft and exudative meat (PSE) & Anemia \\
& Acid Meats \\
& Myopathy \\
\hline $\begin{array}{l}\text { Dry, firm and dark meat (DFD) } \\
\text { Traumatic injury }\end{array}$ & Exudative Myopathy of pigs \\
& Strained meats \\
Mortality on arrival at the slaughterhouse & Injury \\
Decubitus during transportation & Traumatic injury \\
& Dead on arrival \\
\hline
\end{tabular}


602,006 condemned carcasses $(1.4 \%)$ (Table 2). In fifteen days at a slaughterhouse, RIBEIRO et al. (2016) reported a percentage of condemnation of $0.14 \%$ in 512 pigs killed. GARCIA-DIEZ \& COELHO (2014) observed, in Lisbon (Portugal), a rate of $0.4 \%$ losses during transport, pre-slaughter and total carcasses condemnation for 161,001 pigs transported within a month. However, BUENO et al. (2013), on condemnation data of pigs at a slaughterhouse in Dourados (Mato Grosso do Sul, Brazil) between 2007 and 2009 , with 1,369,332 slaughtered pigs, observed $1.3 \%$ of condemned carcasses. HARLEY et al. (2014) evaluated the prevalence of lesions associated with pig welfare using data from an Irish slaughterhouse and realized that, for the 3,422 pigs slaughtered during $7 \mathrm{~d}$, there was $2.5 \%$ of condemnation. Perhaps the fact that many studies used the data from one or few slaughterhouses and excluded partial condemnation data can explain the variation in published results.

Among the 602,006 condemned carcasses, $90,426(15.0 \%)$ were related to IWT causes. Considering the literature, this percentage was expected to be higher. GARCIA-DIEZ \& COELHO (2014) observed that $38.0 \%$ of total condemnation were probably associated with low level of welfare during transport; for RIBEIRO et al. (2016), such result was $20.0 \%$. In the work by BUENO et al. (2013), at least $57.0 \%$ of the condemned carcasses were related to the welfare problems during tranport and pre-slaughter handling. HARLEY et al. (2014) observed that $72.0 \%$ of the pigs presented tail lesions and $44.0 \%$ presented pelvic bursitis, though these lesions are not uniquely related to transport and have not necessarily resulted in condemnation. In the SIGSIF there is a lack of information on important lesions related to welfare in the transport, which possibly contributed to the differences between our results and the literature. Thus, the results suggested there is a need for additional lesion identification at SIGSIF, such as cutaneous lesions, bruises and fractures. Furthermore, there is a need for training with focus on the identification of lesions related to low welfare in the transport.

Considering condemnation data, $58.0 \%$ were partial and $4.0 \%$ total condemnation events, respectivelly 351,431 and 250,575 carcasses (Table 2). Results demonstrated higher balance between the two kinds of condemnation types than in other researches, maybe due to the higher coverage of number of slaughterhouses and time length of the data set, as well as the care concerning the inclusion of both types of condemnation in this study. RIBEIRO et al. (2016) reported $25.0 \%$ of the total condemnation and $75.0 \%$ of the partial ones; GARCIA-DIEZ \& COELHO (2014) did not evaluate partial condemnation; BUENO et al. (2013) did not differentiate between partial and total condemnation types; HARLEY et al. (2014) observed $83.0 \%$ of partial and $17.0 \%$ of total condemnation events. The studies with Brazilian data seem to identify higher rates of total condemnation. In this way, our results collaborated for the understanding of the prevalence of partial and total condemnation at Brazilian slaughterhouses under SIF by presenting more robust data and by suggesting ways for the constant monitoring of such prevalences in association with indicators of animal welfare.

Among the carcasses condemned because of some IWT, 81.0\% (73.516) were partially condemned, while for the carcasses condemned for GTI, this rate was of $54.0 \%(277,788)$. There was a significant association between type of condemnation and the indicator $(\mathrm{p}<0.001)$, and IWT was more associated with partial condemnation. RIBEIRO et al. (2016) verified that all condemnations related to low pre-slaughter welfare were partial condemnations.

Table 2 - Condemnation data per type of indicator and of condemnation data registered at SIF's Management Information System ([SIGSIF][UdW1][M2]) (Jan/2011-Dec/2016).

\begin{tabular}{|c|c|c|c|c|c|}
\hline Slaughtered Pigs ${ }^{\text {a }}$ & Indicator and destination & $\begin{array}{c}\text { Condemned } \\
\text { carcasses }\end{array}$ & $\begin{array}{l}\text { Percentage of } \\
\text { condemnation }\end{array}$ & $\begin{array}{l}\text { Annual } \\
\text { Average }\end{array}$ & $\begin{array}{c}\text { Annual Standard } \\
\text { Deviation }\end{array}$ \\
\hline \multirow{4}{*}{41313434} & $\mathrm{IWT}^{\mathrm{b}}$ & 90426 & 15.0 & 15071 & 4434 \\
\hline & General $^{\mathrm{c}}$ & 511580 & 85.0 & 85263 & 32910 \\
\hline & Partial Condemnation & 351431 & 58.0 & 58572 & 21260 \\
\hline & Total Condemnation & 250575 & 42.0 & 41763 & 34889 \\
\hline
\end{tabular}

${ }^{\mathrm{a}}$ Slaughtered pigs from January 2011 to December $2016 .{ }^{\mathrm{b}}$ Indicators of animal welfare during transportation. ${ }^{\mathrm{c}}$ General Type Indicators. 
However, distinction between types of condemnation and their respective causes in similar studies is rare. Although, lesions associated with IWT tend to enable specific removal of the affected parts, it remains high priority to improve transport conditions, since there is relevant welfare impairment and economic loss for both partial and total condemnation events.

The year 2014 had the highest number of condenation; the sums of slaughtered pigs and condemned carcasses per year are shown in Figure 1-A. For the six years studied, considering the average condemnation occurrences, trends for September and March to be the months with higher and lower number of condemned carcasses were observed; with respectively $10,683 \pm 5,502$ and 6,121 $\pm 2,106$ (Figure 1-B). No seasonal pattern for either IWT or IGT condemnation numbers was observed. Figure 1-C represents the sums, averages and standard deviation of condenation data by IWT and GTI, per year.

Among the IWT reasons, traumatic lesion, pale, soft and exsudative (PSE) and dead on arrival were registered during all years. The other IWT reasons were registered in 2011, 2012, 2013 and 2014, and there was not a common pattern amongst causes for the condemnation. As for GIT, the adherence prevalence was outstanding along all the studied period, and peaks of contaminations cases were observed in 2011, 2012, 2013, 2014 and 2016. In relation to the IWT, 12.1\% of condemnation was a result of the traumatic lesion (72,759 carcasses, $80.0 \%$ of the IWT condemnation total), $2.5 \%$ due to PSE $(15,144,17.0 \%) ; 0.4 \%$ related to dead on arrival $(2,327,2.6 \%)$ and $0.03 \%$ by other IWT $(196,0.23 \%)$. Thus, traumatic lesion and PSE characteristics represented $97.0 \%$ of total condemnation rates due to IWT.

The percentage of condemnation due to traumatic lesions was inferior to that reported in other publications. BUENO et al. (2013) observed $20.0 \%$ for condemnation events due to fractures and hematomas and of $0.24 \%$ for the condemnation caused by bruises. At a slaughterhouse in Rio Grande do Sul (Brazil), bruises and fractures were the principal causes of partial condemnation, adding up to $20.0 \%$ of all cases (RIBEIRO et al., 2016). A large part of the literature makes reference to this type of lesion; however, percentages for condemnation are not always reported. HARLEY et al. (2014) identified, on the loin region, severe bruises in $16.0 \%$ of the animals, which were not directly associated with condemnation, suggesting that the number of condemnation events give only an idea of a minimum level of occurrence and that there are more injuries. Nonetheless, data indicated that bruises are a prevailing problem, which is relevant for animal welfare reasons.

Our results in terms of condemnation percentages may not represent the total for traumatic lesions, since at SIGSIF there is no room to record fracture and hematoma events. Thus; although, such lesions might have been identified as traumatic lesions, part of them may have been included in other groups of reasons for condemnation available in the system. Additionally, fractures and hematomas may not have been registered at all, since these terms are not in the System.

The percentage of $2.5 \%$ of condemnation resulting from PSE is close to that reported by CORREA et al. (2013), of $3.0 \%$ in the summer and $1.0 \%$ in the winter. Nevertheless, in our study there was no correlation between the rate of condemnation and the meteorological data. SANTIAGO et al. (2012), when evaluating the influence of the meteorological data on the occurrence of PSE, concluded that the prevalence of PSE was more related to gender than to the environmental conditions, such as temperature and humidity rates. Additionally, conditions and handling during transport seem to reflect in affect the percentage of condemnation due to PSE. GARCIA-DIEZ \& COELHO (2014) reported 0.5\% of condemnation, considering that during the period of the research, the certification required from drivers and transport companies became compulsory. Thus, future research on the effect of driver certification on the prevalence of PSE seems warranted. In this regard, it has been demonstrated that the continuous updating and training given to the professionals involved in the handling and pre-slaughter procedures have positive effects on animal welfare and decrease the condemnation rates in the slaughterhouse (PARANHOS DA COSTA et al., 2012). Also, BROOM (2008) suggested that bonus remuneration for employees according to decreases in carcass lesion occurrence increases animal welfare and bonuses for faster transport trips are not recommended.

Publications citing percentages of mortality are more frequent in comparison with other indicators. Mortality rate on arrival at the slaughterhouse was $0.4 \%$, representing $2.6 \%$ of the condemnation by IWT. Evaluating different slaughterhouses in Portugal, Italy, Finland, Brazil and Spain, DALMAU et al. (2016) observed the percentage of $0.2 \%$ of pigs dead on arrival. In a review related to the losses during pig transport, RITTER et. al (2009) identified an average of $0.3 \%$ of mortality in the United States, between 2000 and 2007. According to data collection performed 


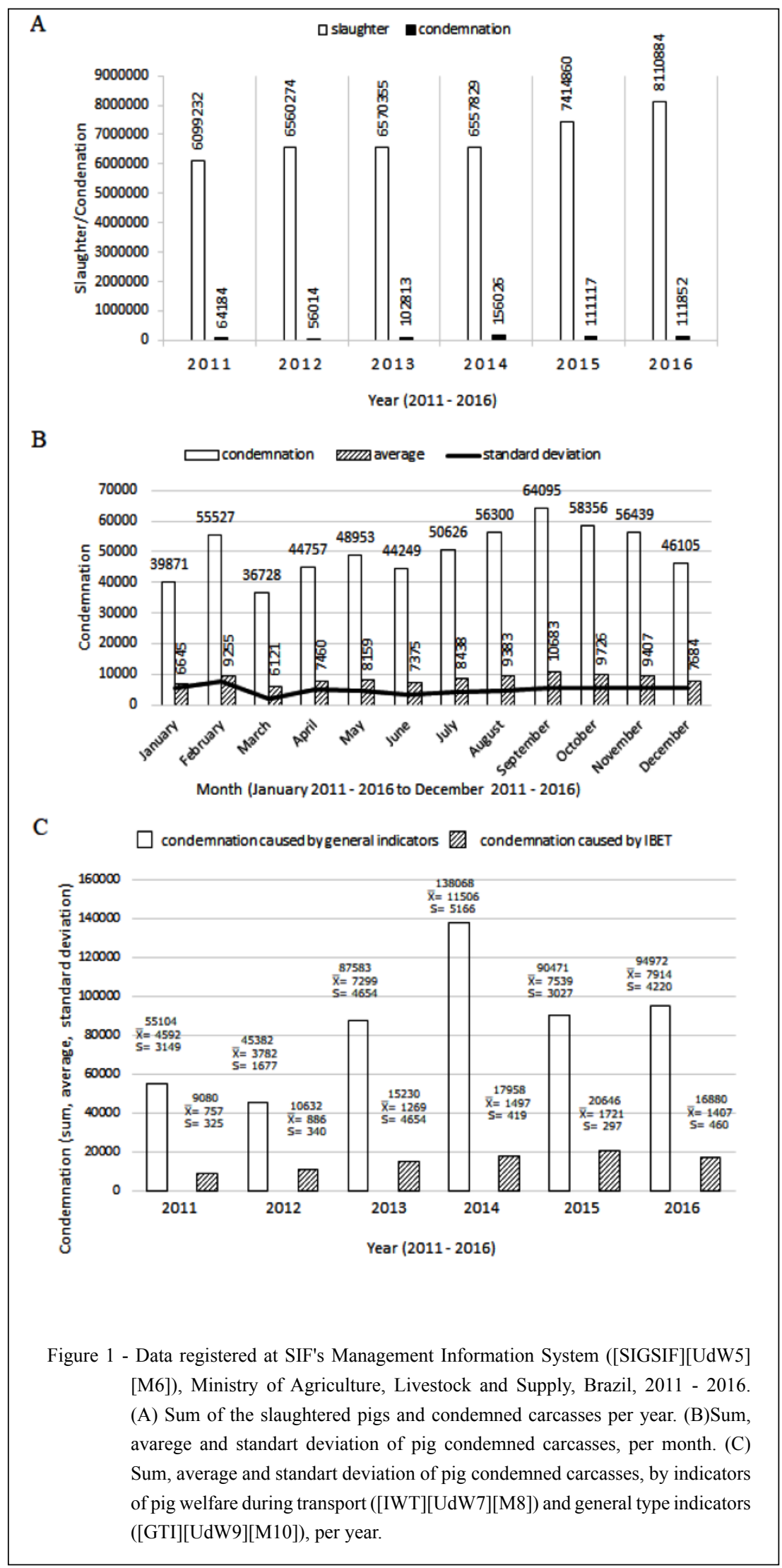

Ciência Rural, v.49, n.1, 2019. 
by a Canadian agricultural cooperative, in 2008 the percentage of pigs dead on arrival was $0.17 \%$ (MARTEL, 2010), and a similar rate was also observed by DEWEY et al. (2009) in other Canadian study. In the research done by GARCIA-DIEZ \& COELHO (2014), there was $0.09 \%$ of mortality; in Italy, NANNONI et al. (2016) observed a percentage of $0.03 \%$. The density in which the pigs were transported in the Italian study may have contributed to the reduced rate, since it complied with the European legislation, and the maximum density was $235 \mathrm{~kg} / \mathrm{m}^{2}$ (EC, 2005). Analysing the Brazilian data, BUENO et al. (2013) observed that the mortality as a result of transport was the principal condemnation cause, with a rate of $0.3 \%$, accounting for $26.6 \%$ of all condemnation events. Thus, the percentage of $0.4 \%$ is higher than the percentages reported in other studies, disclosing the need for improvements in the conditions of pig transport in Paraná. Possible related factors are the infrastructure of the boarding place and of the truck, distances traveled, road conditions, density on trucks and the attention given to the people involved, regarding their knowledge on ethological handling and humane attitudes to animals.

It was detected $0.03 \%$ of condemnation associated with other IWT, corresponding to $0.23 \%$ of total IWT condenation. Low rates may be associated with the lack of details given in the assessment of carcasses with features of dry, firm and dark meat (DFD) and of lesions caused by the decubitus. Identification of DFD was done mostly based on visual observation and the measurement of $\mathrm{pH}$ was not frequently peformed. Training on the features of lesions caused by prolonged decubitus to the professionals involved in the identification is scarce; additionally, there are only a few seconds available for such assessment. As for PSE, studies on the occurrence of DFD are rarely discussed in connection with the percentages of carcass condemnation in the slaughterhouse. Assessing the occurrence of DFD, considering the effect of the different seasons, CORREA et al. (2013) observed $8.0 \%$ of carcasses with DFD features in winter and $1.0 \%$ in the summer; GAJANA et al. (2013) reported $32.0 \%$ in winter and $7.0 \%$ in the summer, while MAGANHINI et al. (2007) observed a percentage of $1.0 \%$ in pig loins in a Brazilian region where low temperatures were predominant. Perhaps the lack of correlation between the rate of condemnation and the metereological data in our database is related to the low diagnostic power of SIGSIF data on the DFD occurrence.

The literature on pigs is scarce in relation to the lesions generated by long periods lying in the same position. Nevertheless, SOMMAVILLA et al. (2017) identified that during the transport to the slaughterhouse, $32.3 \%$ of the pigs remained in standing position, $17.7 \%$ remained sitting and $44.7 \%$ remained lying during the whole traveled distance, which suggests that many pigs are at risk of developing congestive lesions. The evaluation of carcasses and the diagnosis of ischaemic lesions at the slaughterhouses seem to be a viable propostion for improving knowledge on lesions caused by prolonged decubitus during transport.

\section{CONCLUSION}

The analysis and monitoring of SIGSIF data on condemnation rates related to welfare indicators are useful for the improvement of knowledge regarding the welfare problems pigs face during transport and for the proposition of strategies to mitigate their suffering. The present research revealed the need for improvements in the conditions of pig transport to the slaughterhouses in Paraná, especially on the density of animals during transit, traveled distances, and animal handling. This research also allowed for the recognition of the need for the inclusion of a field on the SIGSIF data collection forms for the registration of the lesions that occurred during transport, considering ante and post-mortem evaluation at the slaughterhouse, since such information contributes to the assessment of the animal welfare. Additional opportunities of improvement included the standardization of terms that already exist in the system, with refinement according to lesion definitions in the scientific literature; further detailed information on the measurement of the indicators, with measurements that are not only visual; the elaboration of norms, instructions and training for the professionals involved in the animals assessment and in the inspection of the carcasses and products deriving from pig slaughter. Overall, the SIGSIF structure seems adequate to the development of an effective animal welfare monitoring system, providing relatively small adjustments which were added to the system.

\section{DECLARATION CONFLICTING OF} INTEREST

The authors declare no conflict of interest.

\section{AUTHORS' CONTRIBUTIONS}

MT and CM conceived and designed the experiments. MT carried out data collection, bibliographic review and statistical analyses of data. MT prepared the draft of the manuscript. All authors critically revised the manuscript and approved of the final version. 


\section{REFERENCES}

BRAZILIAN ANIMAL PROTEIN ASSOCIATION (ABPA)

Available from: $<$ http://abpa-br.com.br/setores/suinocultura $>$. Accessed: Oct. 12, 2016. (ABPA, 2016).

BROOM, D. M. The welfare of livestock during road transport. In: M. APPLEBY; V. CUSSEN, L. GARCÉS; L. LAMBERT; J. TURNER (Editors) Long Distance Transport and the Welfare of Farm Animals, Wallingford: CABI, 2008. Cap.7, p.157-181

BUENO, L. S. et al. Swine carcass condemnation in commercial slaughterhouses. Revista MVZ Córdoba, v.18, n³3, p.38363842, 2013. Available from: <http:/www.scielo.org.co/scielo. php script $=$ sci arttext $\&$ pid $=$ S0122-02682013000300013 > Accessed: Nov. 05, 2016.

CORREA, J. A. et. al. Welfare and carcass and meat quality of pigs being transported for two hours using two vehicle types during two seasons of the year. Canadian Journal of Animal Science, v.93, n1, p.43-55, 2013. Available from: <http:/www.nrcresearchpress. com/doi/abs/10.4141/cjas2012-088\#.WQd-CdLyvIU>. Acessed Feb. 12, 2017. doi: 10.4141/CJAS2012-088

EUROPEAN FOOD SAFETY AUTHORITY (EFSA). Scientific Opinion on the use of animal-based measures to assess welfare in pigs. EFSA Journal, v.10 (1): 2512, 2012. Available from: <http:/ onlinelibrary.wiley.com/doi/10.2903/j.efsa.2012.2512/epdf> Accessed: Jul. 06, 2016.

DALMAU, A. et al. Application of the welfare quality ${ }^{\mathbb{R}}$ protocol at pig slaughterhouses. Animal Welfare, v. $18, \mathrm{n}^{\circ} 4$, p.497-505, 2009. Available from: <https://www.researchgate. net/profile/Pol_Llonch/publication/233610150_Application_ of the Welfare QualityR protocol at pig slaughterhouses/

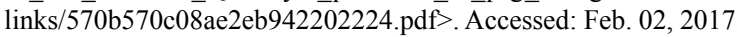

DALMAU, A. et al. Application of the welfare quality ${ }^{\mathbb{R}}$ protocol in pig slaughterhouses of five countries. Livestock Science, v.193 p.78-87, 2016. Available from: <http://www.livestockscience. com/article/S1871-1413(16)30221-9/fulltext>. Accessed: Mar. 03, 2017. doi: http://dx.doi.org/10.1016/j.livsci.2016.10.001.

DEWEY, C. et al. Factors associated with in-transit losses of fattening pigs. Animal Welfare, v.18, n4, p.355-361, 2009. Available from: <http://www.ingentaconnect.com/contentone/ ufaw/aw/2009/00000018/00000004/art00005>. Accessed: Jan. 30, 2017.

EUROPEAN CONVENTION - EC. Council Regulation $\mathrm{N}^{\circ} 1 / 2005$ : On the protection of animals during transport and related operations and amending. Diretivas 64/432/EEC e 93/119/ EC and Regulation (EC) $\mathrm{N}^{\circ} 1255 / 97$. Official Journal of the European Union, L3, 22/12/2004, p.01-44, 2005. Available from: <http://eur-lex.europa.eu/legal-content/EN/TXT/?uri=urise rv:OJ.L_.2005.003.01.0001.01.ENG\&toc $=$ OJ:L:2005:003:TOC $>$. Accessed: Oct. 16, 2016. (EC, 2005).

GAJANA, C. S. et al. Effects of transportation time, distance, stocking density, temperature and lairage time on incidences of pale soft exudative (PSE) and the physico-chemical characteristics of pork. Meat Science, v.95, p.520-525, 2013. Available from: $<$ http://www.sciencedirect.com/science/article/pii/ S0309174013002222>. Accessed: Mar. 30, 2017. doi: 10.1016/j. meatsci.2013.05.028.
GARCIA-DIEZ, J.; COELHO, A. C. Causes and factors related to pig carcass condemnation. Veterinarni Medicina, v.59, p.194 201, 2014. Available from: <http://vri.cz/docs/vetmed/59-4-194. pdf>. Accessed: Feb. 14, 2017.

GEVERINK, N. A. et al. Effects of regular moving and handling on the behavioral and physiological responses of pigs to preslaughter treatment and consequences for subsequent meat quality. Journal of Animal Science, v.76, $\mathrm{n}^{\circ} 8$, p.2080-2085, 1998. Available from: <https://www.animalsciencepublications. org/publications/jas/articles/76/8/2080>. Accessed: Jan. 8, 2017. doi: $10.2527 / 1998.7682080 x$.

INSTITUTO NACIONAL DE METEREOLOGIA (INMET). Available from: $<$ http://www.inmet.gov.br/portal/>. Accessed: Jan. 15, 2017. (INMET, 2017).

HARLEY, S. et al. Docking the value of pigmeat? Prevalence and financial implications of welfare lesions in Irish slaughter pigs. Animal Welfare, v.23, p.275-285, 2014. Available from: <https:// www.researchgate.net/publication/264058115>. Accessed: Jan. 15, 2017. doi: 10.7120/09627286.23.3.275.

MAGANHINI, M. B. et al. Meats PSE (Pale, Soft, Exudative) and DFD (Dark, Firm, Dry) of an industrial slaughterline for swine loin. Food Science and Technology, v.27, p.69-72. Campinas, 2007. Available from: <http:/www.scielo.br/scielo.php?script=sci_artte xt\&pid=S0101-20612007000500012>. Accessed: Apr. 01, 2017. doi: $10.1590 / \mathrm{S} 0101-0612007000500012$.

MARTEL, A. Les pertes dans le transport, agir pour les diminuer, La Coop Profid'Or, Agriculture, Quincaillerie, Cheval, 2010. Available from: $<$ https://coopprofidor.wordpress.com/2010/10/20/ les-pertes-dans-le-transport-agir-pour-les-diminuer/ $>$. Accessed: Feb. 01, 2017.

MINISTRY OF AGRICULTURE, LIVESTOCK AND SUPPLY -MINISTÉRIO DA AGRICULTURA, PECUÁRIA E ABASTECIMENTO (MAPA). Available from: <http://www agricultura.gov.br/animal/especies/suinos>. Accessed: Nov. 01, 2016. (MAPA, 2016)

MINISTRY OF AGRICULTURE, LIVESTOCK AND SUPPLY - MINISTÉRIO DA AGRICULTURA, PECUÁRIA E ABASTECIMENTO (MAPA). Decree n' 9.013 of March 29, 2017. Regulates Law $n^{\circ} 1.283$, of December 18,1950 and Law $\mathrm{n}^{\circ} 7.889$, of November 23, 1989, which provide for the industrial and sanitary inspection of products of animal origin. Available from: <http://www.planalto.gov.br/ccivil_03/_ato2015-2018/2017/ decreto/D9013.htm>. Accessed: Apr. 04, 2017. (MAPA, 2017).

NANNONI, E. et al. Evaluation of pre-slaughter losses of Italian heavy pigs. Animal Production Science. Available from: $<\mathrm{http}: / /$ www.publish.csiro.au/AN/AN15893>. Accessed: Mar. 15, 2017. Published electronically on Sept. 26, 2016. doi: 10.1071/AN15893.

PARANHOS DA COSTA, M.J.R. et al. Strategies to promote farm animal welfare in Latin America and their effects on carcass and meat quality traits. Meat Science, v.92, p.221-226, 2012.

PEREIRA, T. L.; CORASSA, A. Flow transport of pigs for slaughter in the State of Mato Grosso. Brazilian Journal of Animal Health and Production, v.15, N $\mathrm{N}^{\circ} 4,2014$. Available from: <http://www.scielo.br/scielo.php?pid=S151999402014000400022\&script $=$ sci abstract\&tlng $=\mathrm{pt}>$. Accessed: May. 9, 2016. doi: 10.1590/S1519-99402014000400022. 
R, CORE TEAM. R: A Language and Environment for Statistical Computing, Translation. Vienna, Austria: R Foundation for Statistical Computing, 2016.

RIBEIRO, G. F. et al. Causes of partial and total condemnation of porcine carcasses. VI Brazilian Congress of Production Engineering, Ponta Grossa-Paraná, 2016. Available from: $<\mathrm{http}: /$ aprepro.org.br/conbrepro/2016/anais2016.php >. Accessed: Feb. 10,2017

RITTER, M. J. et al. Review: Transport losses in market weight pigs: I. A review of definitions, incidence, and economic impact. The Professional Animal Scientist, v.25, p.404-414, 2009 Available from: $<$ http://www.sciencedirect.com/science/article/pii/ S108074461530735X>. Accessed: Jan. 20, 2017. doi: 10.15232 S1080-7446(15)30735-X

STATE SECRETARIAT FOR AGRICULTURE AND FOOD SUPPLY OF PARANÁ - SECRETARIA DE ESTADO DA AGRICULTURA E DO ABASTECIMENTO DO PARANÁ (SEAB). Available from: $<$ http://www.agricultura.pr.gov.br/arquivos/ File/deral/nppr.pdf $>$. Accessed: Apr. 21, 2017. (SEAB, 2017).
Federal Inspection Service Management Information System Sistema de Informações Gerenciais do Serviço de Inspeção Federal (SIGSIF). Available from: <http://sigsif.agricultura.gov. br/sigsif_cons/\%21sigsif.ap_condenacao_especie_rep_cons $>$. Accessed: Feb. 01, 2017. (SIGSIF, 2017).

SANTIAGO, J. C. et al. Incidence of PSE (pale, soft, exsudative) meat in pigs due to pre-slaughter rest time and sex. Brazilian Archives of Veterinary Medicine and Zootechnics, v.64, $\mathrm{n}^{\circ} 6$, p.1739-1746, 2012. Available from: <http://www.scielo.br/scielo. $\mathrm{php}$ ? script $=$ sci arttext\&pid $=\mathrm{S} 0102-09352012000600045>$. Accessed:Feb. 10, 2017. doi: 10.1590/S0102-09352012000600045.

SOMMAVILLA, R. et al. Season, transport duration and trailer compartment effects on blood stress indicators in pigs: relationship to environmental, behavioral and other physiological factors, and pork quality traits. Animals-Open Acess Journal, v.7, $n^{\circ} 8$, 2017. Available from: <http://www.mdpi.com/2076-2615/7/2/8>. Accessed: Mar. 30, 2017. doi: 10.3390/ani7020008.

SIEGEL, S. Non-parametric statistics for the behavioral sciences. Translation: McGraw-Hill São Paulo, 1975. 